\title{
Kebijakan Kepala Sekolah dalam Meningkatkan Minat Belajar Peserta Didik pada Pembelajaran PAI
}

\author{
Nilam Sari ${ }^{1}$, Murniyetti ${ }^{2}$ \\ sarinilam286@gmail.com ${ }^{1}$, murniyetti@fis.unp.ac.id ${ }^{2}$ \\ Universitas Negeri Padang1,2
}

\begin{tabular}{|c|c|}
\hline ART & \multirow{12}{*}{$\begin{array}{l}\text { The purpose of this study was to examine the principal's } \\
\text { policy in increasing student interest in learning PAI at SMA } \\
\text { Negeri } 13 \text { Padang. This research uses qualitative research } \\
\text { with a case study approach (case study). Sources of data were } \\
\text { taken through direct interviews with informants consisting of } \\
\text { school principals, Islamic Religious Education teachers, and } \\
\text { studentsOverall, the results of the study found that, first, in the } \\
\text { aspect of the principal's policy in increasing students' interest } \\
\text { in learning in PAI learning, there were four steps taken by the } \\
\text { principal, namely implementing a learning policy outside the } \\
\text { classroom, making religious events, conducting simulations, } \\
\text { then giving punishments. educating according to Islamic law } \\
\text { for students who commit violations, as well as giving rewards } \\
\text { or awards to students who have a disciplined attitude in good } \\
\text { study. Second, the supporting factors experienced by school } \\
\text { principals and educators in increasing students' interest in } \\
\text { learning are the existence of adequate facilities and } \\
\text { infrastructure, cooperation of school elements, collaboration } \\
\text { of educators and parents. Third, the inhibiting factors for } \\
\text { school principals and educators in increasing student interest } \\
\text { in learning are the lack of student knowledge in PAI learning, } \\
\text { discipline, family factors, and social influences. }\end{array}$} \\
\hline Article history: & \\
\hline Received, 07 Februari 2022 & \\
\hline Revised, 26 Februari 2022 & \\
\hline Accepted, 28 Februari 2022 & \\
\hline Keywords: & \\
\hline Kebijakan, Kepala Sekolah, & \\
\hline Minat Belajar & \\
\hline Conflict of Interest: & \\
\hline None & \\
\hline Funding: & \\
\hline None & \\
\hline
\end{tabular}

Corresponding Author: Nilam Sari, Department Islamic Education Faculty of Social Science Universitas Negeri Padang, Indonesia, Email: sarinilam286@gmail.com, Phone No.: +628228834-0378

Copyright(C2022, Author(s)

\section{Pendahuluan}

Pendidikan merupakan usaha sadar untuk mengembangkan potensi sumber daya manusia (SDM) melalui kegiatan pengajaran. Salah satu contoh kegiatanya adalah dalam kegiatan belajar pada peserta didik. Belajar merupakan usaha melatih otak kita supaya mendapat suatu kepandaian. Dari pernyataan tersebut dapat diartikan bahwa belajar merupakan suatu proses pertumbuhan dalam diri seseorang yang didapatkan dalam penambahan kualitas dan kuantitas tingkah laku seperti peningkatan 
Nilam Sari dan Murniyetti: Kebijakan Kepala Sekolah dalam Meningkatkan Minat Belajar...

pengetahuan, kecakapan, daya pikir, sikap, kebiasaan, dan lain-lain (Sulistyorini, 2009).

Dalam Sistem Pendidikan Nasional, jalur pendidikan dibagi menjadi tiga, yaitu pendidikan informal, pendidikan formal, dan pendidikan nonformal. Pendidikan informal adalah kegiatan pendidikan yang dilakukan oleh keluarga dan lingkungan berbentuk kegiatan belajar mandiri. Jalur pendidikan formal adalah jalur pendidikan yang dilaksanakan dalam jenjang yaitu pendidikan dasar, pendidikan menengah, dan pendidikan tinggi. Sedangkan jalur pendidikan nonformal adalah pendidikan yang diselenggarakan bagi warga masyarakat yang memerlukan layanan pendidikan yang berfungsi sebagai pengganti, penambah, dan atau pelengkap pendidikan formal dalam rangka mendukung pendidikan sepanjang hayat (Sumiarti, 2016). Sekolah menengah atas (SMA) merupakan pendidikan tingkat ketiga dimana setelah tamat dari SMA akan melanjutkan kejenjang perguruan tinggi. Lingkungan sekolah dikomando oleh kepala sekolah dan dibantu oleh staf dalam proses pendidikan peserta didik. Kepala sekolah wajib berkolaborasi dengan guru dalam memberikan pola pengembangan yang baik bagi peserta didik. Untuk menciptakan lingkungan sekolah yang baik maka sebuah lembaga harus memiliki kepala sekolah yang berkompeten.

Kepala sekolah adalah orang yang di percayakan untuk memimpin pendidikan disebuah lembaga pendidikan. Kepala Sekolah harus mampu menciptakan situasi belajar mengajar yang baik. Ini berarti ia harus mampu mengelola "school plant", pelayanan-pelayanan khusus sekolah, dan fasilitas-fasilitas pendidikan sehingga guruguru dan siswa memperoleh kepuasan dalam menikmati kondisi-kondisi kerja, mengelola personalia pengajar dan peserta didik, membina kurikulum yang memenuhi kebutuhan anak, dan mengelola catatan pendidikan. Semua ini diharapkan, agar Kepala sekolah dapat memajukan program pengajaran disekolanya. Untuk dapat melaksanakan tanggung jawab tersebut, kepala sekolah harus memiliki pendidikan dan pengalaman yang diperlukan bagi kepemimpinan pendidikan (Hendiyat Suetopo, 1988). Kepala sekolah yang baik ialah kepala sekolah yang mampu membuat suatu kebijakan demi kemajuan suatu lembaga pendidikan baik itu mengenai siswa maupun guru.

Kebijakan merupakan suatu rangkaian konsep dan asas yang menjadi sebuah pedoman dasar rencana dalam pelaksanaan pekerjaan, kepemimpinan serta cara bertindak. Kebijakan ini berbeda dengan sebuah perarturan dan hukum. Jika hukum dapat memaksakan atau melarang suatu perilaku contohnya kewajiban untuk membayar pajak. sedangkan kebijkan hanya menjadi sebuah patokan atau pedoman tindakan yang paling mungkin memperoleh hasil yang diinginkan (Taufiqurokhman, 2014) oleh karena itu kebijakan kepala sekolah juga berpengaruh terhadap minat belajar peserta didik khususnya pada pelajaran PAI.

Pembelajaran pendidikan Agama Islam adalah upaya sadar dan terencana dalam menyiapkan peserta didik untuk mengenal, memahami, menghayati, mengimani, bertakwa, berakhlak mulia, mengamalkan ajaran agama islam yang bersumber pada kitab suci Alquran serta al-Hadits, melalui kegiatan bimbingan, pengajaran, latihan, dan juga menggunakan pengalaman. Mata pelajaran pendidikan agama islam (PAI) merupakan mata pelajaran yan g wajib bagi peserta didik di SMA Negeri 13 Padang kelas X, XI, maupun XII. Mata pelajaran pendidikan agama islam (PAI) memiliki tujuan agar peserta didik mampu mengimplementasikan pembelajaran pendidikan agama islam baik di lingkungan sekolah, keluarga, dan kehidupan sehari-hari. Pembelajaran 
PAI di SMA Negeri 13 Padang sudah melaksanakan sistem pembelajaran daring dan luring, sistem daring (dalam jaringan) dilaksanakan satu minggu pembelajaran kemudian satu minggunya lagi di laksanakan secara luring (luar jaringan).

Berdasarkan observasi yang dilakukan di SMA Negeri 13 Padang pada tanggal 1 sampai 4 September penulis telah melakukan wawancara bersama kepala sekolah dan guru PAI bahwa di SMA Negeri 13 Padang pada saat pembelajaran berlangsung peneliti lebih terfokus pada kelas XII dikarenakan peserta didik kelas XII akan mempersiapkan diri untuk memasuki jenjang dunia perkuliahan. Oleh karena itu minat belajar harus lebih ditingkatkan lagi guna mencapai tujuan pembelajaran yang baik. Setelah peneliti mengamati minat belajar peserta didik kelas XII di SMA Negeri 13 Padang masih mengalami minat belajar yang minim terutama pada pembelajaran PAI, padahal sudah semua metode serta perangkat pembelajaran yang digunakan secara bervariasi, namun kenyataanya siswa masih banyak yang tidak minat dalam pembelajaran PAI, dimana hal ini bisa di lihat dari sikap peserta didik dalam mengikuti proses belajar mengajar seperti ada siswa minta izin mau ke kamar mandi, tetapi ternyata ia berjalan berkeliling di belakang sekolah, bahkan ada juga yang duduk di kantin. Selain itu, ada pula yang ngobrol dengan teman, serta ada juga siswa yang tidur-tiduran saja ketika belajar. Gejala-gejala tersebut menunjukkan bahwa siswa kelas XII memiliki minat belajar yang rendah saat mengikuti pembelajaran PAI.

\section{Tinjauan Pustaka}

Kebijakan adalah kepandaian, kemahiran dan kebijaksanaan, rangkaian konsep dan asas yang menjadi garis besar dan dasar rencana dalam pelaksanaan pekerjaan, kepemimpinan dan cara bertindak oleh pemerintah, organisasi dan sebagainya untuk manajemen dalam mencapai sasaran (Syaiful Sagala, 2009). Dalam hal ini, kebijakan berkenaan dengan gagasan pengaturan organisasi dan merupakan pola formal yang sama-sama diterima pemerintah/lembaga sehingga dengan hal itu mereka berusaha mengejar tujuannya. Menurut Gamage dan Pang dalam kebijakan adalah terdiri dari pernyataan tentang sasaran dan satu atau lebih pedoman yang luas untuk mencapai sasaran tersebut sehingga dapat dicapai yang dilaksanakan bersama dan memberikan kerangkah kerja bagi pelaksanaan program (Syaiful Sagal, 2009).

Faktor yang menentukan perubahan, pengembangan, atau reskontruksi organisasi adalah terlaksananya kebijakan organisasi sehingga dapat dirasakan bahwa kebijakan tersebut benar-benar berfungsi dengan baik. Dengan demikian dapat disimpulkan bahwa kebijakan dibuat untuk menjadi pedoman dalam bertindak, mengarahkan kegiatan dalam organisasi untuk mencapai tujuan yang telah ditetapkan. Adapun fungsi dari kebijan ini iyalah: Fungsi alokasi, fungsi inquiri, dan fungsi komunikasi. Tujuan dilakukannya kebijakan dilihat dari ruang lingkup waktunya terdapat tiga jenis perencanaan nasional pendidikan yang perlu dibuat secara teratur dan sinambung. Ketiga jenis kebijakan tersebut meliputi kebijakan jangka panjang, menengah dan pendek.

Implementasi kebijakan pada prinsipnya adalah cara yang dilaksanakan agar sebuah kebijakan tersebut dapat mencapai tujuan. dijelaskan oleh Putt dan Springer, Implementasi kebijakan adalah serangkaian aktifitas dan keputusan yang memudahkan pernyataan kebijakan dalam pembutan kebijakan terwujud ke dalam praktek (Syafaruddin, 2008). Salah satu kebijakan kepala sekolah dalam meningkatkan minat belajar siswa adalah sebagai berikut: pemberian pengawasan yang begitu ketat 
Nilam Sari dan Murniyetti: Kebijakan Kepala Sekolah dalam Meningkatkan Minat Belajar...

kepada peserta didik, membiasakan sholat berjemaah apabila waktu sholat sudah masuk guru wajib memberhentikan pembelajaran, Pemberian hukuman kepada peserta didik, Pemberian reward atau hadiah kepada peserta didik (Gunawan, 2019).

Menurut Bimo Walgito dikutip oleh Ramayuli dalam metodologi pengajaran agama islam: menyatakan bahwa minat yaitu "Suatu keadaan dimana seseorang mempunyai perhatian terhadap sesuatu dan disertai dengan keinginan untuk mengetahui dan mempelajari maupun membutuhkan lebih lanjut" (Ramayulis, 2001). Secara singkat yang dimaksud dengan minat belajar adalah kecenderungan dan perhatian dalam belajar. Dalam pengertian lain minat belajar adalah: Kecenderungan perhatian dan kesenangan dalam beraktivitas, yang meliputi jiwa dan raga untuk menuju perkembangan manusia seutuhnya, yang menyangkut cipta, rasa, karsa, kognitif, afektif dan psikomotor lahir batin (Wijaya, 2001).

Berdasarkan pengertian para ahli dalam merumuskan minat belajar, maka terdapat beberapa indikator dalam menentukan minat belajar siswa, di antaranya: perasaan senang, ketertiban siswa, ketertarikan, dan perhatian peserta didik. Menurut abdul Rahman saleh dalam bukunya yang berjudul Psikologi Suatu Pengantar Dalam Prespektif Islam bahwa faktor yang mempengaruhi timbulnya minat terhadap sesuatu dapat dikelompokkan menjadi dua yaitu yang bersumber dari dalam individu yang bersangkutan (misal: bobot, umur, jenis kelamin, pengalaman, pengalaman kepribadian, perasaan mampu) dan yang berasal dari luar mencakup lingkungan keluarga, lingkungan sekolah dan lingkungan masyarakat (Abdul, 2004).

Ahmad dalam jurnal Susanti (2017) Tafsir mendefenisikan Pendidikan Agama Islam adalah bimbingan yang diberikan oleh seseorang agar orang yang diajarkan dapat berkembang secara maksimal sesuai dengan ajaran Islam, dengan kata lain Pendidikan Agama Islam adalah bimbingan terhadap seseorang agar ia menjadi muslim semaksimal mungkin, muslim disini dimaknai dengan mengetahui semua ajaranajaran yang telah di jelaskan dalam kitab suci Al-quran dan sunnah Rasulullah SAW. Ahmad Nasir menekankan sifat dari aktifitas Pendidikan Islam, yaitu berupa bimbingan sebagai suatu upaya yang tidak hanya ditekankan pada aspek pengajaran (transfer ilmu pengetahuan) tetapi juga arahan, bimbingan, pemberian petunjuk, dan pelatihan menuju arah terbentuknya pribadi muslim yang seutuhnya (Susanti, 2017). Dalam kurikulum Undang-Undang Sisdiknas No. 20 Tahun 2003 Pasal 1 ayat 1, Pendidikan Agama Islam usaha sadar dan terencana untuk mewujudkan suasana belajar dan proses pembelajaran agar peserta didik secara aktif mengembangkan potensi dirinya untuk memiliki kekuatan spiritual keagamaan, pengendalian diri, kepribadian, akhlak mulia, serta keterampilan yang diperlukan dirinya, masyarakat, bangsa, dan negara. Pendidikan Agama Islam yaitu suatu usaha untuk membina serta mengasuh peserta didik untuk senantiasa berada dalam ajaran Islam secara menyeluruh, lalu menghayati tujuan, yang pada tujuan akhirnya dapat mengamalkan yang telah dipelajarinya. Mata pelajaran Pendidikan Agama Islam secara keseluruhannya dalam ruang lingkup Alquran, Hadist, Aqidah Akhlaq, Fiqh atau Ibadah dan Sejarah Kebudayaan Islam.

\section{Metode}

Dalam melakukan penelitian ini penulis ingin memfokuskan perhatian pada implementasi pembelajaran sistem daring dan luring terhadap pembelajaran Pendidikan Agama Islam dengan menggunakan pendekatan atau penelitian kualitatif. 
Penelitian kualitatif adalah penelitian yang menghasilkan data sebuah penjabaran yang berupa sebuah kata-kata baik itu tertulis maupun lisan dari orang-orang dan perilaku yang dapat diamati (Margono, 2010:362). Penelitian deskriptif memiliki tujuan mendeskripsikan apa-apa yang saat ini berlaku. Penelitian ini tidak bertujuan untuk menguji hipotesis dan tidak pula menggunakan hipotesis, namun hanya mendeskripsikan informasi apa adanya sesuai dengan variable (Mardalis, 1990: 26).

Penelitian kualitatif deskriptif adalah jenis penelitian yang menggunakan metode pengumpulan data berupa gambar, kata-kata atau ucapan dari orang-orang serta perilaku yang dapat damati dan bukan berupa angka-angka atau data statistik. Berdasarkan penelitian di atas peneliti model kualitatif bermaksud untuk menjelaskan peristiwa-peristiwa dan kejadian-kejadian yang terjadi pada saat penelitian dilakukan. Adapun alasan penulis menggunakan jenis penelitian kualitatif ini adalah data yang dihasilkan dari penelitian ini berupa data deskriptif yang bersumber dari hasil observasi, wawancara, dan dokumentasi. Penelitian ini menjelaskan serta mendeskripsikan realita atau fakta di lapangan mengenai implementasi sistem daring dan luring terhadap pembelajaran Pendidikan Agama Islam di SMAN 1 Negeri Lubuk Basung kelas X tahun ajaran 2020/2021.

\section{Hasil dan Pembahasan}

\section{Kebijakan kepala sekolah dalam meningkatkan minat belajar peserta didik pada pembelajaran PAI kelas XII di SMA Negeri 13 Padang.}

Berdasarkan hasil wawancara yang dilakukan kepada dua puluh orang informan, hasil analisis secara nyata mendapati bahwa terdapat lima tema penting terkait apa sesunguhnya kebijakan kepala sekolah dalam meningkatkan minat belajar peserta didik dalam pembelajaran PAI. Lima tema tersebut dapat terlihat pada gambar 1 , berikut:

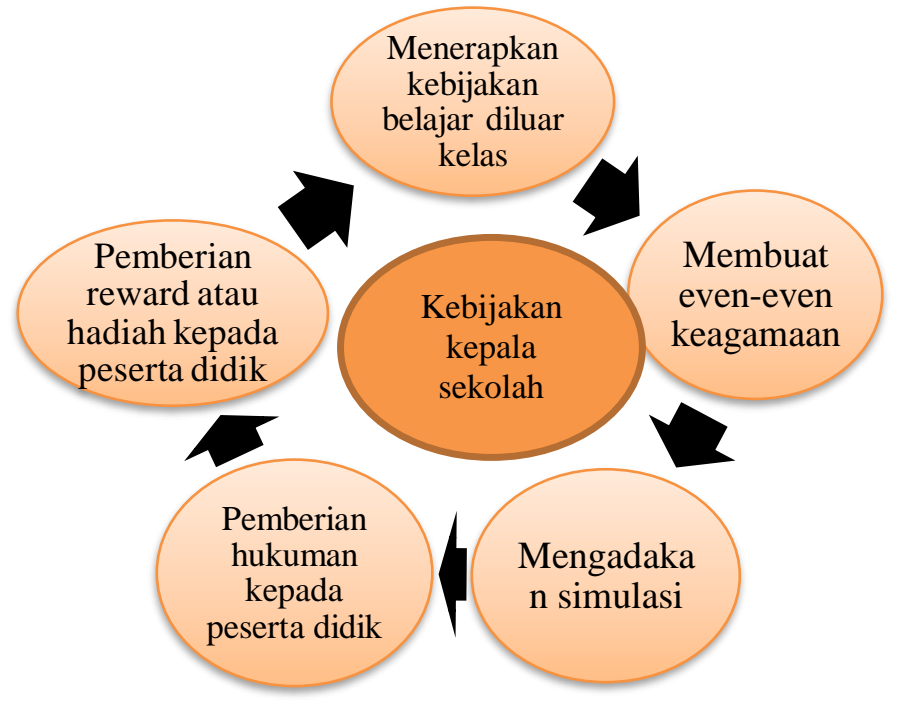

Gambar 1. Deskripsi. Kebijakan kepala sekolah dalam meningkatkan minat belajar peserta didik pada pembelajaran PAI

Berdasarkan gambar 1, dapat penulis jelaskan bahwa setelah diadakan wawancara mendalam dengan informan maka terdapat lima kebijakan kepala sekolah dalam meningkatkan minat belajar peserta didik pada pembelajaran PAI. Kebijakan kepala 
Nilam Sari dan Murniyetti: Kebijakan Kepala Sekolah dalam Meningkatkan Minat Belajar...

sekolah tersebut merupakan kebijakan yang sifatnya tertulis dan tidak tertulis salah satu contohnya kebijakan yang tertulis yaitu menbuat Iven-even keagamaan seperti perlombaan MTQ, sedangkan kebijakan yang tidak tertulis seperti pemberian reward atau hadiah kepada peserta didik. kebijakan yang dilakukan oleh kepala sekolah tidak hanya diterapkan oleh kepala sekolah saja tetapi oleh semua guru yang mengajar di sekolah tersebut. Berdasarkan hasil wawancara bersama bapak zahroni, M.Pd selaku guru kepala sekola sekaligus guru PAI yang berada di SMAN 13 Padang terdapat lima kebijakan kepala sekolah, lima tema tersebut adalah i), Menerapkan kebijakan belajar diluar kelas ii), Membuat even-even keagamaan iii) Mengadakan simulasi, iv) Pemberian hukuman kepada peserta didik, v) Pemberian reward atau hadiah kepada peserta didik.

Agar lebih menarik, berikut ini akan penulis deskripsikan kutipan hasil wawancara dengan informan berdasarkan lima tema sebagaimana telah dijelaskan di atas. Adapun deskripsi wawancara yang akan penulis tampilkan adalah kutipan pernyataan singkat dari informan ketika wawancara dilakukan. Kutipan-kutipan wawancara tersebut walaupun disampaikan informan dalam redaksi bahasa yang sedikit berbeda-beda, namun sebenarnya mempunyai tujuan dan maksud yang kurang lebih sama.

Tema pertama yaitu menerapkan kebijakan belajar diluar kelas, menurut informan salah satu kebijakan kepala sekolah dalam meningkatkan minat belajar peserta didik pada pembelajaran PAI adalah menerapkan kebijakan belajar diluar kelas, Kepala sekolah menerapkan kebijakan belajar di luar kelas agar siswa tidak merasa bosan belajar di dalam kelas. Pembelajaran diluar kelas atau atau out door merupakan cara mengajar guru dengan jalan membimbing siswa di lapangan atau pembelajaran yang mengunakan sumber belajar berupa alam sekitar dan biasa memberikan kesempatan kepada siswa untuk mengalami sendiri, kemudian mentransfer pengetahuan berdasarkan pengalaman yang di miliki.

Tema ini dinyatakan oleh informan sebagaimana petikan wawancara pada tabel 1 berikut: bapak Zahroni, M. Pd (wawancara 27 Oktober 2021), beliau menyampaikan bahwa:

"Sebagai pimpinan sekolah, sekaligus sebagai guru PAI saya menetapkan kebijakan belajar diluar kelas, agar peserta didik yang mengikuti pelajaran tidak merasa bosan belajar di dalam kelas terus. Contohnya saya membuat gazero linterasi, dimana terdapat 3 buah gazero yang diberi nama gazero linterasi a, gazero linterasi b, dan gazero linterasi c serta semua peserta didik bisa belajar dengan alam".

Tema kedua yaitu membuat even-even keagamaan, menurut informan pendidik di SMA Negeri 13 Padang sudah menerapkan kegiatan even-even tentang keagamaan yang diterapkan kepada peserta didiknya, salah satu contohnya adalah dengan mengadakan perlombaan MTQ, mengadakan kegiatan rohis tiap minggunya, mengadakan muhadarah atau kultum setiap hari jum'at diluar ruangan, melaksanakan ngaji bersama sebelum belajar serta semua kebiasaan yang baik yang bertujuan untuk meningkatkan minat belajar peserta didik. Sejalan dengan pendapat Ma'mur Asmani, (2009) mengatakan kebiasaan-kebiasaan yang baik sangat perlu diperhatikan sebagai unsur yang penting dalam proses pembentukan minat belajar peserta didik. Tema ini dinyatakan oleh informan sebagaimana petikan wawancara pada tabel 2 berikut: ibuk Haryani, S.Pd.I (wawancara 02 November 2021) guru PAI kelas XI di SMA Negeri 13 Padang, beliau mengatakan bahwa: 
"Contoh kebijakan yang berhubungan dengan even-even keagamaan yang saya ajarkan sebagai pendidik ialah membiasakan peserta didik untuk selalu membantu sesama muslim yang terkena musibah serta setiap hari sebelum masuk pembelajaran saya menyuruh peserta didik membaca alquran tiap harinya minimal 3 ayat. Bukan hanya siswanya saja kami sebagai guru-guru di SMA Negeri 13 Padang juga melaksanakan ngaji bersama sebelum melakukan kegiatan.

Tema ketiga yaitu mengadakan simulasi, menurut informan Dalam meningkatkan minat belajar peserta didik di SMA Negeri 13 Padang salah satu kebijakan yang dilakukan pihak sekolah ialah dengan mengadakan simulasi atau pengulangan pembelajaran dengan menambah jam belajar di luar pembelajaran. Semua itu dilakukan dengan cara seperti, guru mengadakan jam tambahan sehabis pulang sekolah untuk mengulang pembelajaran yang kemaren di ajarkan atas izin dari kepala sekolah. Tema ini dinyatakan oleh informan sebagaimana petikan wawancara pada tabel 3 berikut: bapak Zahroni, M.Pd sebagai kepala sekolah di SMA Negeri 13 Padang (wawancara 5 November 2021), beliau menyampaikan bahwa:

"Saya sebagai kepala sekolah mengambil keputusan bahwa kebijakan yang telah dibuat harus dijalani dan di terapkan kepada peserta didik di kelas. Semua guru di wajibkan mengadakan stimulasi karna keterbatasan waktu pembelajaran yang diadakan di sekolah, agar smua siswa bisa memahami dan bisa bertanya apa saja yang tidak di pahami dalam belajar,".

Tema keempat yaitu pemberian hukuman kepada peserta didik, menurut informan Di SMA Negeri 13 Padang menerapkan hukuman kepada peserta didik tidak berupa hukuman fisik, peserta didik lebih sering diberi teguran atau arahan. Jika terjadi pelanggaran biasanya dihukum dengan cara disuruh menghafal surah-surah pendek, dan hukuman yang paling sering diberikan ialah dengan teguran saja. Hukuman itu diharapkan mempunyai nilai pendidikan. Artinya peserta didik menyadari bahwa perbuatan yang salah akan membawa akibat yang tidak menyenangkan dan harus dipertanggung jawabkan. Dengan demikian, diharapkan nantinya tidak ada lagi yang melakukan pelanggaran. Tema ini dinyatakan oleh informan sebagaimana petikan wawancara pada tabel 5 berikut: Intana Liyu kelas XII MIPA 1 (wawancara 12 November 2021), intan juga mengatakan bahwa:

"saya selalu senang sekali apabila sudah belajar PAI karna setiap belajar gurunya cendri memberikan sesi tanya jawab dan hadiah bagi dan pujian yang membuat saya berpacu dengan teman dalam merebut pertanyaa tersebut".

Tema kelima yaitu pemberian reward atau hadiah kepada peserta didik, Di SMA Negeri 13 Padang pendidik memberikan penghargaan berupa buku apabila peserta didik menerapkan kedisiplinan dalam belajar di sekolah atau memberikan nilai yang bagus. Contohnya penghargaan yang diberikan pendidik kepada peserta didik ketika di kelas yaitu bagi peserta didik yang mengumpulkan tugas tepat waktu maka akan diberikan nilai tambahan dibanding peserta didik yang mengumpulkan terlambat. Penghargaan tidak saja diberikan dalam bentuk materi namun pendidik juga memberikan penghargaan dalam bentuk sanjungan atau pujian kepada peserta didik. Fungsi pemberian hadiah/ penghargaan salah satunya sebagai nilai mendidik, karena pemberian hadiah/ penghargaan akan memotivasi mereka untuk selalu bersikap disiplin. Tema ini dinyatakan oleh informan sebagaimana petikan wawancara pada tabel 6 berikut:

Faktor Pendukung Kepala Sekolah dan Pendidik dalam Meningkatkan Minat Belajar Peserta Didik di SMA Negeri 13 Padang 
Nilam Sari dan Murniyetti: Kebijakan Kepala Sekolah dalam Meningkatkan Minat Belajar...

Berdasarkan hasil wawancara yang dilakukan kepada dua puluh orang informan, hasil analisis secara nyata mendapati bahwa terdapat tiga tema penting terkait apa sesunguhnya faktor pendukung kepala sekolah dan pendidik dalam meningkatkan minat belajar peserta didik. Tiga tema tersebut dapat terlihat pada gambar 2 , berikut:

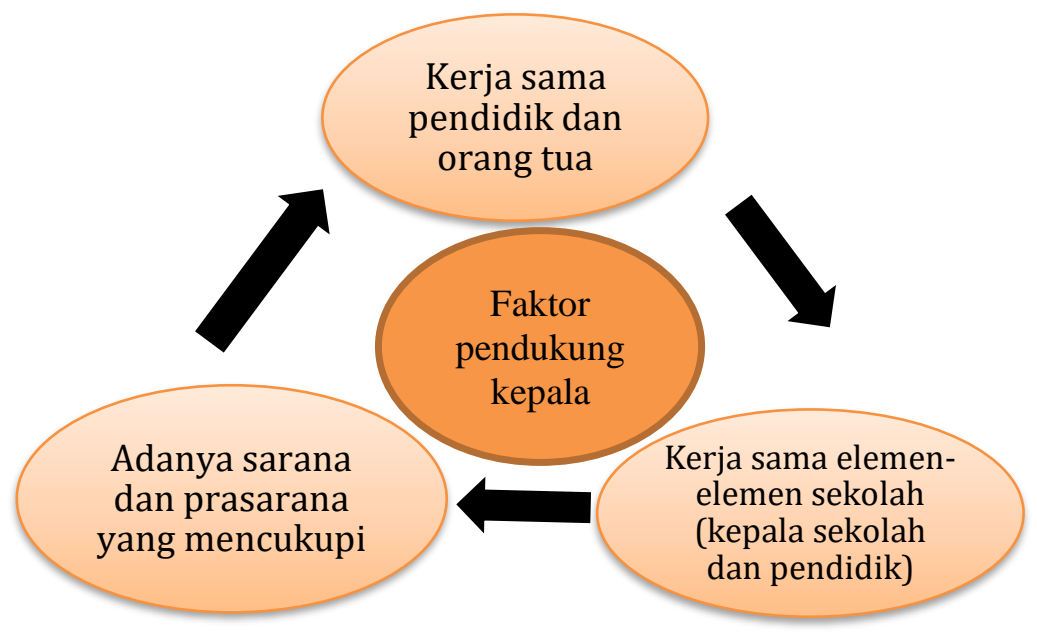

Gambar 2. Deskripsi. faktor pendukung kepala sekolah dan pendidik dalam meningkatkan minat belajar peserta didik

Berdasarkan gambar 2, dapat penulis jelaskan bahwa setelah diadakan wawancara mendalam dengan informan maka terdapat tiga faktor pendukung kepala sekolah dan pendidik dalam meningkatkan minat belajar peserta didik, tiga tema tersebut adalah i), Adanya sarana dan prasarana yang mencukupi ii), Kerja sama elemen-elemen sekolah (kepala sekolah dan pendidik) iii) Kerja sama pendidik dan orang tua

Agar lebih menarik, berikut ini akan penulis deskripsikan kutipan hasil wawancara dengan informan berdasarkan tiga tema sebagaimana telah dijelaskan di atas. Adapun deskripsi wawancara yang akan penulis tampilkan adalah kutipan pernyataan singkat dari informan ketika wawancara dilakukan. Kutipan-kutipan wawancara tersebut walaupun disampaikan informan dalam redaksi bahasa yang sedikit berbeda-beda, namun sebenarnya mempunyai tujuan dan maksud yang kurang lebih sama.

Tema pertama yaitu adanya sarana dan prasarana yang mencukupi, menurut informan Di SMA Negeri 13 Padang untuk mendukung terbentuknya minat belajar peserta didik diperlukan adanya sarana dan prasarana yang lengkap di sekolah. Dimana salah satu contoh serana prasarananya yaitu kepala sekolah dan elemen sekolah lainya membuat gazero linterasi yang terdapat tiga buah gazero yang digunakan untuk belajar atau kregiatan lainya. Tema ini dinyatakan oleh informan sebagaimana petikan wawancara pada tabel 2 berikut: Zahroni sebagai kepala sekolah di SMA Negeri 13 Padang (wawancara 14 November 2021) ialah:

"Saya selaku kepala sekolah berupaya mencukupi semua sarana prasarana yang di gunakan untuk belajar hal ini bertujuan untuk meningkatkan minat peserta didik. Salah satu contoh saya mendirikan gajero linterasi sebanyak tiga bagunan, taman buah, serta perbaharuan mushola menjadi masjid".

Tema kedua yaitu Kerja sama elemen-elemen sekolah (kepala sekolah dan pendidik), menurut informan Di SMA Negeri 13 Padang yang memiliki tanggung jawab 
dalam meningkatkan minat belajar peserta didik adalah semua elemen sekolah baik kepala sekolah, guru pendidik, wakil kurikulum, maupun guru BK. Namun hal yang paling berpengaruh sekali pada minat belajar peserta didik adalah kepala sekolah dan pendidik. Jadi kepala sekolah dan guru memiliki kebijakan serta strategi tertentu dalam meningkatkan minat belajarmpeserta didiknya salah satunya dengan melakukan kerja sama antar elemen-elemen sekolah. Di SMA Negeri 13 Padang para pendidik melakukan kerja sama untuk meningkatkan minat belajar peserta didik. Kerja sama yang dilakukan berupa melakukan rapat terkait perkembangan peserta didik baik itu pengetahuan nya dan juga perilakunya. Pihak sekolah selalu melakukan kontrol harian, mingguan dan bulanan. Ini bertujuan untuk melihat sejauh mana perkembangan minat belajar peserta didik khususnya pada pembelajaran PAI. Tema ini dinyatakan oleh informan sebagaimana petikan wawancara pada tabel 3 berikut: bapak Osmi Hendri sebagai guru PAI kelas XII (wawancara 14 November 2021), beliau mengatakan bahwa:

"Semua pihak sekolah memilih kewajiban untuk meningkatkan minat belajar siswa terutama dalam penerapan pembelajaran PAI. apabila ada salah seorang siswa yang terkena musibah guru-guru serta elemen-elemen sakolah ikut serta dalam pengumpulan dana"

Tema ketiga yaitu Kerja sama pendidik dan orang tua, menurut informan Di SMA Negeri 13 Padang untuk mendukung terbentuknya minat belajar peserta didik diperlukan perhatian dari seorang pendidik dan juga kerja sama orang tua dan sekolah. Kerjasama pihak sekolah dapat diwujudkan dengan cara mengundang orang tua pendidik dalam rapat-rapat yang berkaitan dengan kesiswaan dan juga secara langsung memanggil orang tua peserta didik yang bermasalah atau melakukan pelanggaran. Semua itu dilakukan untuk membicarakan dan memecahkan masalahmasalah agar dapat mengembangkan pribadi peserta didik secara maksimal. Tetapi untuk melakukan kerjasama ini adanya kendala yang terjadi yaitu terkadang wali murid tidak dapat menghadiri rapat sekolah yang berkaitan dengan perkembangan peserta didik di sekolah dengan alasan sibuk kerja.

Tema ini dinyatakan oleh informan sebagaimana petikan wawancara pada tabel 4 berikut: Elsa Adriana murid kelas XII IPA-6 (wawancara 16 November 2021) mengatakan bahwa:

"Dari kecil saya sudah di ajarkan ortu saya untuk membagi waktu di mana waktu bermain, dan di mana waktu belajar. lama kelamaan jadi saya terbiasa untuk belajar di rumah "

\section{Faktor penghambat Pendidik dalam Meningkatkan Minat Belajar Peserta Didik di SMA Negeri 13 Padang}

Berdasarkan hasil wawancara yang dilakukan kepada dua puluh orang informan, hasil analisis secara nyata mendapati bahwa terdapat tiga tema penting terkait apa sesunguhnya faktor penghambat kepala sekolah dan pendidik dalam meningkatkan minat belajar peserta didik. Tiga tema tersebut dapat terlihat pada gambar 2 , berikut: 


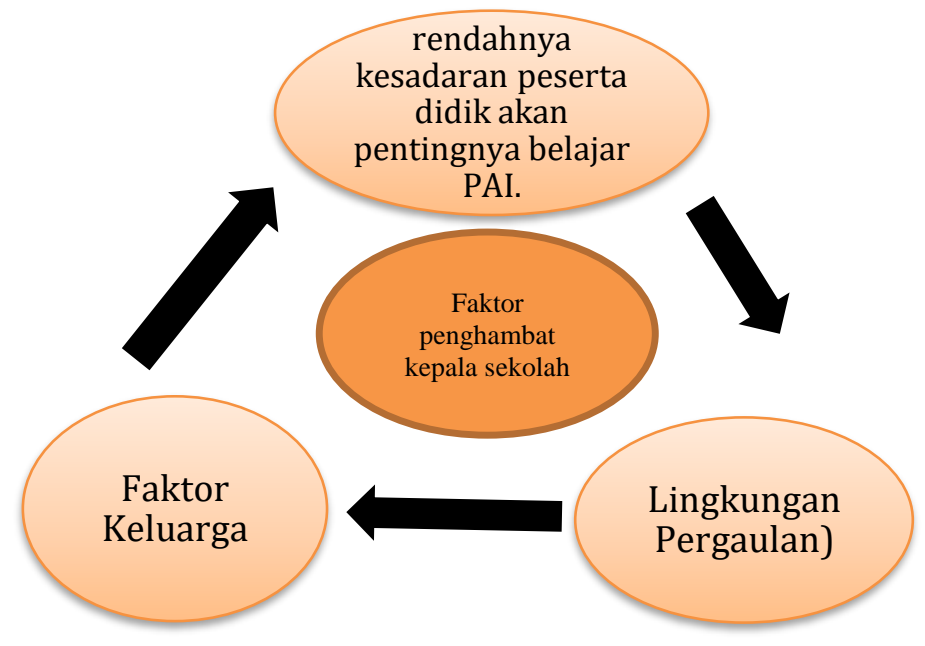

Gambar 2. Deskripsi. faktor pendukung kepala sekolah dan pendidik dalam meningkatkan minat belajar peserta didik

Berdasarkan gambar 2, dapat penulis jelaskan bahwa setelah diadakan wawancara mendalam dengan informan maka terdapat tiga faktor penghambat kepala sekolah dan pendidik dalam meningkatkan minat belajar peserta didik, tiga tema tersebut adalah i), rendahnya kesadaran peserta didik akan pentingnya belajar PAI ii), Faktor Keluarga iii) Lingkungan Pergaulan

Agar lebih menarik, berikut ini akan penulis deskripsikan kutipan hasil wawancara dengan informan berdasarkan tiga tema sebagaimana telah dijelaskan di atas. Adapun deskripsi wawancara yang akan penulis tampilkan adalah kutipan pernyataan singkat dari informan ketika wawancara dilakukan. Kutipan-kutipan wawancara tersebut walaupun disampaikan informan dalam redaksi bahasa yang sedikit berbeda-beda, namun sebenarnya mempunyai tujuan dan maksud yang kurang lebih sama.

Tema pertama yaitu rendahnya kesadaran peserta didik akan pentingnya belajar PAI, menurut informan Salah satu kendala dalam meningkatkan minat belajar peserta didik di SMA Negeri 13 Padang ialah masih rendahnya kesadaran peserta didik akan pentingnya belajar PAI, ini dapat ditemukan dari beberapa peserta didik yang kurang peduli akan belajar PAI, salah satu contohnya banyak peserta didik yang cabut saat belajar, ngobrol, tidur-tiduran dalam belajar serta tidak disiplin dalam belajar. Peraturan atau tata tertib sekolah dibuat dalam rangka membentuk sikap disiplin peserta didik. Apabila peserta didik sudah memiliki kesadaran dalam diri akan pentingnya peraturan maka mereka akan mengerti perilaku mana yang diperbolehkan dan yang dilarang oleh sekolah. Jadi dalam melaksanakan tata tertib di sekolah semua warga sekolah terutama peserta didk seharusnya memiliki kesadaran diri tanpa ada paksaan dari pihak-pihak yang berwenang sehingga dalam membentuk sikap disiplin dalam belajar juga bisa terlaksana dengan baik dan optimal tanpa ada suatu kendala. Tema ini dinyatakan oleh informan sebagaimana petikan wawancara pada tabel 2 berikut: Ibu Haryani, S.Pd.I sebagai guru PAI kelas XI (wawancara 17 November 2021) mengatakan bahwa:

"Sebenarnya mereka dalam belajar suidah memahami materi yang saya sampaikan apalagi saya menyampaaikan materi dengan metode yang berbeda tiap pertemuanya 
hanya saja banyak dari mereka yang sering bilang bahwa sanya dia merasa bosan belajar di dalam ruangan terus".

Tema kedua yaitu faktor Keluarga, menurut informan Dengan melakukan pengawasan secara intensif dan berkala orang tua bisa mengontrol perilaku anak. Ketika anak berperilaku menyimpang maka orang tua harus selalu memberikan pengarahan dan melakukan komunikasi/ pendekatan pada anak. Selain itu, seharusnya di dalam lingkungan keluarga orang tua selalu membiasakan disiplin dalam hal apapun. Misalnya di rumah sebagai orang tua sebagai teladan dan pemimpin anak-anaknya, orang tua menyusun peraturan rumah seperti jadwal sehari-hari dan tugas seluruh anggota keluarga. Jadi dalam hal ini seorang anak dibiasakan untuk hidup teratur dan disiplin sehingga anak akan memiliki tanggung jawab pada dirinya sendiri (Aunillah, 2011) Tema ini dinyatakan oleh informan sebagaimana petikan wawancara pada tabel 3 berikut: bapak Zahroni sebagai kepala sekolah di SMA Negeri 13 Padang (wawancara 17 November 2021), beliau menyampaikan bahwa:

"Dimana saya selaku kepala sekolah dan juga guru PAI masih ada melihat siswa saya yang tidak disiplin salah satu contohnya tidak disiplin dalam mengumpulkan tugas.masih banyak peserta didik yang suka mengirimkan tigasnya pada saat sudah melewati waktu pengiriman tugas."

Tema ketiga yaitu lingkungan pergaulan, menurut informan Di SMA Negeri 13 Padang terkadang peserta didik terpengaruhi oleh teman sebayanya untuk melakukan sebuah pelanggaran, dan ikut-ikutan melakukan sebuah kesalahan. Yang sering terjadi ialah terlambat masuk ke kelas pada jam istirahat telah usai atau keluar masuk pada jam pelajaran berlangsung

Tema ini dinyatakan oleh informan sebagaimana petikan wawancara pada tabel 4 berikut: Ibu Haryani, S.Pd. I sebagai guru PAI kelas XI (wawancara 19 November 2021) juga mengatakan bahwa:

"Di lingkungan sekolah peserta didik sudah pasti diawasi oleh guru. Namun di rumah diharapkan orang tua lah yang berperan besar untuk mengawasi anaknya dan mengajarkan kedisilinan kepada anak nya. Jikaorang tua tidak mengajarkan kedisiplinan kepada anak maka otomatis anak juga tidak disiplin dalam segi apapun".

\section{Simpulan}

Kebijakan kepala sekolah dan pendidik dalam meningkatkan minat belajar peserta didik dalam pembelajaran PAI ialah dengan menerapkan kebijakan belajar di luar kelas, mengadakan even-even keagamaan, mengadakan stimulasi, kemudian memberikan reward atau hadiah bagi mereka yang memiliki minat belajar yang tinggi dilihat dari kerajinanya. Factor pendukung kepala sekolah dan pendidik dalam meningkatkan minat belajar peserta didik ialah adanya sarana dan prasarana yang lengkap, dengan melakukan kerja sama yang baik antar elemen-elemen sekolah (pihak sekolah) contohnya melakukan kontrol harian, mingguan, dan bulanan terkait belajar peserta didik di sekolah. Kemudian pendidik juga melakukan kerja sama yang baik antara pendidik dan orang tua dengan mengundang orang tua peserta didik menghadari rapat tentang kesiswaan, kemudian mendatangkan orang tua ke sekolah untuk menemui wali kelas apabila yang bersangkutan sering kali melakukan pelanggaran. Faktor penghambat yang yang ditemukan pendidik dalam meningkatkan minat belajar peserta didik ialah minimnya pengetahuan peserta didik, kurangnya 
Nilam Sari dan Murniyetti: Kebijakan Kepala Sekolah dalam Meningkatkan Minat Belajar...

kesadaran peserta didik akan pentingnya pembelajaran PAI, faktor dari keluarga yaitu orang tua, dan lingkungan pergaulan baik itu di sekolah maupun di luar sekolah.

\section{Referensi}

Abdul Rahman Saleh. 2004. Psikologi Suatu Pengantar Dalam Prespektif Islam. Jakarta: Kencana.

Emzir. 2009. Metodologi Penelitian Pendidikan Kuantitatif dan Kualitatif. Jakarta: PT. Raja Grafindo Perkasa

Idrus, Ali. 2009. Manajemen Pendidikan Global visi, aksi dan adaptasi. Jakarta: GP Press Mahmud, Psikologi Pendidikan Mutakhir, (Bandung: Sahifa, 2006), 97.

Mardalis. 1990. Metode Penelitian Suatu Pendekatan Proposal. Jakarta: Bumi Aksara. Margono. 2010. Metode Penelitian Pendidikan. Jakarta: Rineka Cipta.

Mu'min, Kholid. 2015. "Kebijakan Kepala Sekolah dalam Meningkatkan Mutu Siswa di SMK Ma'arif NU 1 Ajibarang," Skripsi. Purwokerto: IAIN Purwokerto

Mularsih, Karwono dan Heni. 2017. Belajar dan Pembelajaran. Depok: Raja Grafindo Persada

Mulyasa. 2012. Manajemen dan Kepemimpinan Kepala Sekolah. Jakarta: Bumi Aksara Ramayulis. 2001. Metodologi Pengajaran Agama Islam. Jakarta: Kalam Mulia.

Slamento. 2010. Belajar dan Faktor-faktor yang Mempengaruhinya, Jakarta: PT. Rineka Cipta.

S., Andi Abu Daus. 2010. "Strategi Kepala Sekolah Memotivasi Minat Peserta Didik Belajar Pendidikan Agama Islam di SMA Negeri 2 Kendari," Tesisi. Makasar: Universitas Islam Negeri Alaudin Makasar

Soemanto, Hendiyat Soetopo dan Wasty. 1988. Kepemimpinan dan Supervisi Pendidikan. Jakarta: Bina Aksara

Sugiono. 2014. Metode Penelitian Kombinasi, Kualitatif dan Kuantitatif (Mixedmetods). Bandung: Alfabeta.

Syafaruddin. 2015. Kepemimpinan Pendidikan Kontemporer, Bandung: Citapustaka Media.

Syaiful Sagala.2009. Administrasi Pendidikan Kontemporer. Bandung: Alfabeta.

Wijaya Wina. 2001. Strategi Pembelajaran. Bandung: Prenda Media Group. 